\title{
Methane oxidation linked to chlorite dismutation
}

\section{Laurence G. Miller ${ }^{*}$, Shaun M. Baesman ${ }^{1}$, Charlotte I. Carlström ${ }^{2}$, John D. Coates ${ }^{2}$ and Ronald S. Oremland ${ }^{1}$}

1 United States Geological Survey, Menlo Park, CA, USA

${ }^{2}$ Department of Plant and Microbial Biology, University of California, Berkeley, CA, USA

Edited by:

Hans Karl Carlson, University of California, Berkeley, USA

Reviewed by:

Min Chen, University of Sydney, Australia

Paula V. Welander, Stanford

University, USA

${ }^{*}$ Correspondence:

Laurence G. Miller, United States

Geological Survey, MS/480, 345

Middlefield Rd., Menlo Park, CA

94025, USA

e-mail: lgmiller@usgs.gov
We examined the potential for $\mathrm{CH}_{4}$ oxidation to be coupled with oxygen derived from the dissimilatory reduction of perchlorate, chlorate, or via chlorite $\left.\mathrm{ClO}_{2}^{-}\right)$dismutation. Although dissimilatory reduction of $\mathrm{ClO}_{4}^{-}$and $\mathrm{ClO}_{3}^{-}$could be inferred from the accumulation of chloride ions either in spent media or in soil slurries prepared from exposed freshwater lake sediment, neither of these oxyanions evoked methane oxidation when added to either anaerobic mixed cultures or soil enriched in methanotrophs. In contrast, $\mathrm{ClO}_{2}^{-}$amendment elicited such activity. Methane $(0.2 \mathrm{kPa})$ was completely removed within several days from the headspace of cell suspensions of Dechloromonas agitata CKB incubated with either Methylococcus capsulatus Bath or Methylomicrobium album BG8 in the presence of $5 \mathrm{mM} \mathrm{ClO}_{2}^{-}$. We also observed complete removal of $0.2 \mathrm{kPa} \mathrm{CH}_{4}$ in bottles containing soil enriched in methanotrophs when co-incubated with D. agitata CKB and $10 \mathrm{mM} \mathrm{ClO}_{2}^{-}$. However, to be effective these experiments required physical separation of soil from $D$. agitata $\mathrm{CKB}$ to allow for the partitioning of $\mathrm{O}_{2}$ liberated from chlorite dismutation into the shared headspace. Although a link between $\mathrm{ClO}_{2}^{-}$and $\mathrm{CH}_{4}$ consumption was established in soils and cultures, no upstream connection with either $\mathrm{ClO}_{4}^{-}$or $\mathrm{ClO}_{3}^{-}$was discerned. This result suggests that the release of $\mathrm{O}_{2}$ during enzymatic perchlorate reduction was negligible, and that the oxygen produced was unavailable to the aerobic methanotrophs.

\section{INTRODUCTION}

In-situ production of $\mathrm{CO}_{2}$ by microbial activity is encouraged during enhanced oil recovery as a means of reducing oil viscosity and improving flow characteristics (Lazar et al., 2007; Youseff et al., 2009). Further, targeted growth of microbes and intentional precipitation of solid phase minerals can be applied to selectively decrease permeability and direct flow to enhance oil recovery (Jenneman et al., 1984; Zhu et al., 2013). These enhancements rely on the availability of appropriate electron acceptors to supply oxidant to microbes utilizing hydrocarbons or other reduced compounds as electron donors. Considerable attention has been paid thus far to the use of sulfate, nitrate or nitrite as electron acceptors in these applications (Youseff et al., 2009) with sulfate less favored because its reduction results in $\mathrm{H}_{2} \mathrm{~S}$ and leads to oil souring (Gieg et al., 2011). There has been recent interest in the use of perchlorate or chlorate, together known as (per)chlorate as electron acceptors. However, little is known about the fate of (per)chlorate in anoxic environments like oil reservoirs. Here we examine the potential reaction of (per)chlorate and chlorite with the low molecular weight hydrocarbon methane.

Chemical reduction of perchlorate is generally quite slow (Urbansky, 2002). However, under anoxic conditions dissimilatory perchlorate reducing bacteria (DPRB) rapidly reduce (per)chlorate to form chlorite. Chlorite thus formed is further degraded by these bacteria using chlorite dismutase to produce $\mathrm{Cl}^{-}$and $\mathrm{O}_{2}$ (Rikken et al., 1996; Kostan et al., 2010; Mlynek et al., 2011). These microbial processes reduce (per)chlorate from both natural (Rao et al., 2007; Kounaves et al., 2010) and anthropogenic (Coates and Achenbach, 2004) sources. Degradation of intentionally added (per)chlorate is therefore likely in the proximity of hydrocarbon reservoirs given the abundance of suitable electron donors. There is a potential for $\mathrm{O}_{2}$ liberation during this process (see reaction 1 below) that may be used by aerobic bacteria to oxidize aromatic compounds (benzene, naphthalene, catechol) via oxygenase-dependent pathways in otherwise anoxic soils and sediments (Coates et al., 1998, 1999a; Coates and Achenbach, 2004; Weelink et al., 2007; Carlström et al., 2013). A similar phenomenon was noted that could link biological oxidation of arsenite to the reduction of chlorate ions, presumably also by liberation of $\mathrm{O}_{2}$ (Sun et al., 2010). This type of interaction has not been extended to the oxidation of low molecular weight hydrocarbons such as methane $\left(\mathrm{CH}_{4}\right)$.

Methane is produced by geothermal and microbial processes in the Earth's crust (Martini et al., 1996) and in marine and terrestrial sediments (Cicerone and Oremland, 1988). Methane is removed photochemically in the atmosphere by reaction with hydroxyl radicals but the most important removal mechanism in aqueous and terrestrial environments is by the action of anaerobic and aerobic methane oxidizing microbes (Cicerone and Oremland, 1988; Boetius et al., 2000). Significant quantities of methane are associated with oil reservoirs (Jones et al., 2007; Gieg et al., 2008) hence we hypothesize that $\mathrm{ClO}_{2}^{-}$disproportionation, and by extension dissimilatory reduction of the upstream $\mathrm{ClO}_{4}^{-}$ 
or $\mathrm{ClO}_{3}^{-}$ions, could be linked to aerobic $\mathrm{CH}_{4}$ oxidation by a biochemical release of $\mathrm{O}_{2}$ :

$$
\begin{array}{r}
\mathrm{ClO}_{2}^{-} \rightarrow \mathrm{Cl}^{-}+\mathrm{O}_{2} \quad \Delta \mathrm{G}^{\mathrm{o}^{\prime}}=-135 \mathrm{~kJ} / \mathrm{mol} \mathrm{ClO}_{2}^{-}(1) \\
\frac{\mathrm{CH}_{4}+2 \mathrm{O}_{2} \rightarrow \mathrm{CO}_{2}+2 \mathrm{H}_{2} \mathrm{O} \quad \Delta \mathrm{G}^{\mathrm{o}^{\prime}}=-842 \mathrm{~kJ} / \mathrm{mol} \mathrm{CH} 4}{\mathrm{Net} \mathrm{CH}_{4}+2 \mathrm{ClO}_{2}^{-} \rightarrow \mathrm{CO}_{2}+2 \mathrm{Cl}^{-}+2 \mathrm{H}_{2} \mathrm{O}} \\
\Delta \mathrm{G}^{\mathrm{o}^{\prime}}=-1114 \mathrm{~kJ} / \mathrm{mol} \mathrm{CH}_{4}
\end{array}
$$

Two other well-studied microbiological processes can achieve a net oxidation of $\mathrm{CH}_{4}$ under prevailing anaerobic conditions, (1) a reverse process of methanogenesis involving "ANME" archaea in syntrophy with bacterial sulfate- or sulfur-reduction (Hinrichs et al., 1999; Boetius et al., 2000; Milucka et al., 2012) and (2) nitrite-linked $\mathrm{CH}_{4}$ oxidation that putatively liberates $\mathrm{O}_{2}$ via $\mathrm{NO}$ dismutation as achieved by Methylomirabilis oxyfera (Ettwig et al., 2010). In our study we explored the potential for aerobic $\mathrm{CH}_{4}$ oxidizing bacteria to utilize oxygen produced by DPRB during (per)chlorate reduction and chlorite dismutation.

\section{MATERIALS AND METHODS PREPARATION OF CULTURES}

The DPRB Dechloromonas agitata $\mathrm{CKB}$ was grown at $30^{\circ} \mathrm{C}$ under $\mathrm{N}_{2}$ on $20 \mathrm{mM}$ sodium acetate and $10 \mathrm{mM} \mathrm{NaClO} 4$ using phosphate buffer media (PBM) consisting of the following salts in solution (g/liter): $\mathrm{Na}_{2} \mathrm{HPO}_{4}$ (0.971), $\mathrm{NaH}_{2} \mathrm{PO}_{4}$ (0.379), $\mathrm{NH}_{4} \mathrm{Cl}$ $(0.25)$ plus $10 \mathrm{ml} / \mathrm{l}$ vitamins and $10 \mathrm{ml} / \mathrm{l}$ mineral stock solution (Sun et al., 2009). Methylococcus capsulatus Bath, Methylosinus trichosporium OB3b, and Methylomicrobium album BG8, were grown and maintained at $30^{\circ} \mathrm{C}$ on air $+30 \mathrm{kPa} \mathrm{CH}_{4}$ using nitrate mineral salts media (NMS; Whittenbury et al., 1970). Cultures (1 1) for washed cell suspensions were harvested during late exponential phase, centrifuged $(7000 \times \mathrm{g})$, and washed twice with medium lacking substrates and vitamins. Final suspension volumes ranged from 5 to $150 \mathrm{ml}$. Cell concentrations at the start of incubations ranged from $1.8 \times 10^{8}$ cells $\mathrm{ml}^{-1}$ to $6.9 \times 10^{8}$ cells $\mathrm{ml}^{-1}$.

\section{PREPARATION OF SOILS AND SLURRIES}

Soil from the seasonally exposed shoreline of Searsville Lake previously shown to harbor methanotrophic activity (Oremland and Culbertson, 1992) was air dried for two days at room temperature before sieving $(<1 \mathrm{~mm})$ to assure uniformity of soil particle size. Dried soil was stored for several weeks in stoppered 11 glass flasks with air headspace and periodically augmented with $0.2 \mathrm{kPa}$ $\mathrm{CH}_{4}$ after consumption had removed all of the previously added $\mathrm{CH}_{4}$ (4-6 days). Soil with thusly enhanced methanotrophic activity was used to determine $\mathrm{CH}_{4}$ uptake in studies with added $\mathrm{ClO}_{4}^{-}$ and $\mathrm{ClO}_{2}^{-}$in the absence of $\mathrm{O}_{2}$.

Sediment slurries were prepared by adding $100 \mathrm{ml} \mathrm{SeFr2}$ freshwater media (flushed with $20 \mathrm{kPa} \mathrm{CO} / 20 \mathrm{kPa} \mathrm{N}_{2}$; Miller et al., 2013) to $10 \mathrm{~g}$ Searsville Lake soil in $\mathrm{N}_{2}$ flushed serum bottles $(160 \mathrm{ml})$. Slurry $\mathrm{pH}$ was adjusted to 7.1 using $1 \mathrm{ml}$ of $1 \mathrm{M}$ $\mathrm{NaHCO}_{3}$. Slurries were incubated under $\mathrm{N}_{2}$ headspace following periodic amendments with 1 to 2 mmoles acetate and 0.5 to $1 \mathrm{mmole} \mathrm{ClO}_{4}^{-}$. Slurries were periodically sampled by syringe using $22 \mathrm{~g}$ needles and filtered through a $0.2 \mathrm{um}$ Spin-X centrifuge tube. Acetate and $\mathrm{ClO}_{4}^{-}$amendments were made after both were depleted (usually several days to weeks) during which time copious quantities of $\mathrm{CH}_{4}$ were produced. Slurries with enhanced perchlorate reducing activity were used to determine methane uptake activity in the presence or absence of added $\mathrm{O}_{2}$.

\section{MEASUREMENT OF (PER)CHLORATE REDUCTION AND CHLORITE DISMUTASE ACTIVITY}

Aliquots of washed cell suspension of $D$. agitata CKB were distributed into stoppered and $\mathrm{N}_{2}$ flushed $25 \mathrm{ml}$ Balch tubes containing $10 \mathrm{ml} \mathrm{PBM}$ amended with $5 \mathrm{mM}$ acetate and $10 \mathrm{mM} \mathrm{NaClO}_{4}$, $\mathrm{NaClO}_{3}$, or $\mathrm{NaClO}_{2}$. Initial cell densities were $1.8 \times 10^{8}$ cells per $\mathrm{ml}$. The headspace was sampled over 7 days by syringe for $\mathrm{CO}_{2}$ and $\mathrm{O}_{2}$. Aqueous samples $(0.3 \mathrm{ml})$ were collected by syringe for analysis of dissolved acetate and anions $\left(\mathrm{Cl}^{-}, \mathrm{ClO}_{4}^{-}, \mathrm{ClO}_{3}^{-}\right.$, and $\mathrm{ClO}_{2}^{-}$). A short-term (10 min) experiment was conducted to follow $\mathrm{ClO}_{2}^{-}$disproportionation. In this study, triplicate samples were sacrificed at pre-determined times. Activity was stopped by addition of $0.1 \mathrm{ml} 4 \mathrm{~N} \mathrm{NaOH}$ before measurement of headspace $\mathrm{O}_{2}$. Aqueous samples were subsequently collected for analysis of dissolved anions $\left(\mathrm{Cl}^{-}\right.$and $\left.\mathrm{ClO}_{2}^{-}\right)$.

\section{INCUBATIONS WITH MIXED CULTURES}

Mixtures $(10 \mathrm{ml})$ of $M$. capsulatus Bath and D. agitata CKB were prepared by adding washed cell suspensions of the cultures together in $\mathrm{N}_{2}$ flushed Balch tubes $(25 \mathrm{ml})$ sealed with butyl rubber stoppers. Methane $(0.2 \mathrm{kPa})$ was introduced by syringe to all tubes and $\mathrm{NaClO}_{2}(5 \mathrm{mM})$ was added to 3 tubes at the start of the incubation which was conducted at $37^{\circ} \mathrm{C}$. Headspace $\mathrm{CH}_{4}$ was monitored over 1 day. Single tubes were prepared without addition of $\mathrm{ClO}_{2}^{-}$or without one of the cultures (i.e., no D. agitata CKB or no M. capsulatus Bath) to act as negative controls. A tube containing only $M$. capsulatus Bath under an air headspace acted as a positive control.

Additional microcosms were prepared in serum bottles (37 or $67 \mathrm{ml}$ ) using washed cell suspensions of D. agitata CKB and M. trichosporium OB3b or M. album BG8. Inocula were either combined in bottles $(5 \mathrm{ml}$ each) in one aqueous phase or kept separate by placing methanotrophs $(1 \mathrm{ml})$ inside an open-topped glass tube contained within the bottles before flushing with $\mathrm{N}_{2}$ and later adding $D$. agitata CKB $(5 \mathrm{ml})$ by syringe to the bottom of the bottles. In this manner, the cultures were segregated but shared a common headspace. Methane $(0.2 \mathrm{kPa})$ was introduced by syringe to all bottles and $\mathrm{NaClO}_{4}, \mathrm{NaClO}_{3}$, or $\mathrm{NaClO}_{2}$ ( 5 or $10 \mathrm{mM}$ ) was added aseptically to start the incubations which were conducted at $28^{\circ} \mathrm{C}$. Headspace $\mathrm{CH}_{4}$ and aqueous anions were monitored over time. Controls were prepared without additions of $\mathrm{ClO}_{2}^{-}$.

\section{INCUBATIONS WITH ${ }^{14} \mathrm{C}$-LABELED $\mathrm{CH}_{\mathbf{4}}$}

Washed cell suspensions ( $5 \mathrm{ml}$ each) of D. agitata CKB and $M$. trichosporium $\mathrm{OB} 3 \mathrm{~b}$ were added together to $\mathrm{N}_{2}$ flushed serum bottles $(13 \mathrm{ml})$. Radiolabeled ${ }^{14} \mathrm{CH}_{4}(5 \mu \mathrm{Ci}$; specific activity $=$ $21 \mu \mathrm{Ci} / \mu$ mole) was added along with $1 \mathrm{kPa} \mathrm{CH}_{4}$ to the headspace of each bottle. Perchlorate $(5 \mathrm{mM})$ was added to triplicate bottles and $\mathrm{ClO}_{2}^{-}(5 \mathrm{mM})$ was added to a single bottle by syringe 
to start the incubation which was conducted at $30^{\circ} \mathrm{C}$. Gas samples for analysis of ${ }^{14} \mathrm{CH}_{4}$ and ${ }^{14} \mathrm{CO}_{2}$ were collected by syringe. At the end of the incubation, samples were acidified using $0.5 \mathrm{ml}$ of $1.2 \mathrm{~N} \mathrm{HCl}$ to cause dissolved inorganic carbon $\left(\mathrm{DIC}=\mathrm{HCO}_{3}^{-}\right.$ $+\mathrm{CO}_{3}^{-2}$ ) to react to form $\mathrm{CO}_{2}$ gas which was partitioned into the headspace. The headspace was again sampled by syringe. Control incubations consisted of single bottles of $M$. trichosporium OB3b alone under an air headspace and D. agitata CKB alone under $\mathrm{N}_{2}$.

\section{INCUBATIONS WITH SOIL SLURRIES}

Slurry microcosms were prepared in $\mathrm{N}_{2}$ flushed serum bottles (57 ml) containing $5 \mathrm{~g}$ of dried Searsville Lake soil with enhanced methanotrophic activity to which $10 \mathrm{ml}$ Searsville Lake sediment slurry with enhanced perchlorate reducing activity (above) was added. Half the bottles were maintained under $\mathrm{N}_{2}$ while half were flushed with air. Substrate $\left(5 \mathrm{mM} \mathrm{ClO}_{4}^{-}\right.$or $\left.\mathrm{ClO}_{2}^{-}\right)$was added by syringe followed by $0.5 \mathrm{ml} \mathrm{CH}_{4}(1 \mathrm{kPa})$. Incubations were conducted at $22^{\circ} \mathrm{C}$. Headspace and liquid samples were collected by syringe over 9 days.

\section{INCUBATIONS WITH CULTURES PLUS SOIL}

Soil microcosms were prepared in serum bottles $(67 \mathrm{ml})$ using washed cell suspensions of D. agitata $\mathrm{CKB}$ and dried Searsville Lake soil which was enhanced in methanotrophic activity (above). Soil (2 g) was placed inside open-topped glass tubes contained within the bottles prior to sealing and flushing with $\mathrm{N}_{2}$. Subsequently, D. agitata $\mathrm{CKB}(10 \mathrm{ml})$ was added by syringe to the bottom of the bottles followed by aseptic addition of $5 \mathrm{mM}$ acetate. The culture and the soil were thus segregated under a common headspace. Methane $(0.1 \mathrm{kPa})$ was introduced by syringe to all bottles and $10 \mathrm{mM} \mathrm{NaClO} 4, \mathrm{NaClO}_{3}$, or $\mathrm{NaClO}_{2}^{-}$ was added to D. agitata $\mathrm{CKB}$ to start the incubations. Incubations were conducted at $22^{\circ} \mathrm{C}$. Headspace $\mathrm{CH}_{4}$ and $\mathrm{CO}_{2}$ and aqueous acetate and anions were monitored over 7 days.

\section{ANALYTICAL}

Headspace $\mathrm{O}_{2}$ was determined by ECD-GC using a molecular sieve $5 \mathrm{~A}$ column $(3.2 \mathrm{~mm}$ O.D. $\times 2.4 \mathrm{~m})$ operated at $75^{\circ} \mathrm{C}$ using hydrocarbon-free UHP $\mathrm{N}_{2}$ carrier. Background $\mathrm{O}_{2}$ was minimized by flushing syringes and needles with $\mathrm{O}_{2}$-free $\mathrm{N}_{2}$ prior to sampling. The detection limit was $0.05 \mathrm{mmol} \mathrm{O}_{2} / \mathrm{L}$. Headspace $\mathrm{CH}_{4}$ and $\mathrm{CO}_{2}$ were determined by FID- and TCD-GC, respectively (Miller et al., 2013). Cell densities were determined by direct cell counting of liquid samples using acridine orange epi-fluorescence microscopy (Hobbie et al., 1977). Additional aqueous samples, including slurries, were filtered using Spin-X centrifuge filter tubes $(0.2 \mu \mathrm{m}$; Corning Inc., Corning, NY) before determination of dissolved acetate by HPLC (Hoeft et al., 2004) or anions by IC (Miller et al., 2003). Dissolved $\mathrm{ClO}_{4}^{-}$was analyzed separately by suppressed conductivity IC using a Dionex ISC 1100 containing an AS16 analytical column $(4 \times 250 \mathrm{~mm})$ and an AG16 guard column $(4 \times 50 \mathrm{~mm})$ with $0.035 \mathrm{M} \mathrm{NaOH}$ eluent. Measurements of headspace ${ }^{14} \mathrm{CH}_{4}$ and ${ }^{14} \mathrm{CO}_{2}$ were made by gas proportional counting (Culbertson et al., 1981) following TCD-GC analysis of $\mathrm{CH}_{4}$ and $\mathrm{CO}_{2}$ with separation on a Hayesep D column (100/120; 3.2 mm O.D. $\times 4.8 \mathrm{~m})$ using UHP He carrier.

\section{CALCULATIONS}

The total amount of gas in each bottle or tube was calculated from the headspace concentration using Henry's Law and the volumes of gas and liquid present. The dimensionless Henry's Law constants $\left(\mathrm{K}_{H}=\mathrm{C}_{G} / \mathrm{C}_{L}\right)$ used were 31.43 for $\mathrm{O}_{2}, 29.46$ for $\mathrm{CH}_{4}$ and 1.20 for $\mathrm{CO}_{2}$ and were not corrected for ionic strength.

\section{RESULTS}

\section{(PER)CHLORATE REDUCTASE AND CHLORITE DISMUTASE ACTIVITY}

Dissimilatory (per)chlorate reduction by D. agitata CKB resulted in conversion of $85-100 \mu$ moles added $\mathrm{ClO}_{4}^{-}$or $\mathrm{ClO}_{3}^{-}$to $\mathrm{Cl}^{-}$in the presence of $50 \mu$ moles added acetate (Figures 1A,B). Much less $\mathrm{ClO}_{4}^{-}$or $\mathrm{ClO}_{3}^{-}(<15 \mu$ moles $)$ was consumed without added acetate and a corresponding lesser amount of $\mathrm{Cl}^{-}$was produced. These observations suggest endogenous metabolism of intrinsic electron donors such as glycogen or polyhydroxybutyrate (PHB). No activity was observed in killed controls or in incubations with media and chloroxyanions alone (data not shown). Biological reduction of $\mathrm{ClO}_{4}^{-}$or $\mathrm{ClO}_{3}^{-}$and consumption of acetate occurred over approximately 2 days. Chlorite dismutation was much more rapid. More than half of the $100 \mu$ moles $\mathrm{ClO}_{2}^{-}$added was consumed and converted to $\mathrm{Cl}^{-}$before the initial sampling at $T=2 \mathrm{~min}$ (Figure 1C). An additional $20 \mu$ moles $\mathrm{ClO}_{2}^{-}$were consumed over 7 days, however more than $20 \mu$ moles $\mathrm{ClO}_{2}^{-}$remained unreacted at the end.

Carbon dioxide $\left(\mathrm{CO}_{2}\right)$ was the dominant gaseous product of dissimilatory reduction of $\mathrm{ClO}_{4}^{-}$or $\mathrm{ClO}_{3}^{-}$in the presence of acetate (Figures 2A,B). Slightly more $\mathrm{CO}_{2}$ was produced than could be accounted for by the added acetate. Little $\mathrm{CO}_{2}$ was produced without added acetate. Small amounts of $\mathrm{O}_{2}$ (up to $15 \mu$ moles) were produced during incubations with $\mathrm{ClO}_{4}^{-}$or $\mathrm{ClO}_{3}^{-}$. In contrast, $\mathrm{ClO}_{2}^{-}$dismutation resulted in substantial and rapid $\mathrm{O}_{2}$ production (Figure 2C) corresponding to release of $>35 \%$ of the added $\mathrm{ClO}_{2}^{-}$within the first day. As expected, there was no effect of added acetate on disproportionation of $\mathrm{ClO}_{2}^{-}$; however details of the early evolution of $\mathrm{O}_{2}$ were obscured by the coarse sampling schedule.

The pattern of early $\mathrm{O}_{2}$ production during $\mathrm{ClO}_{2}^{-}$dismutation was made clear in a subsequent short-term $(10 \mathrm{~min})$ experiment where $56 \mu$ moles of both $\mathrm{O}_{2}$ and $\mathrm{Cl}^{-}$were produced during the consumption of $56 \mu$ moles of $\mathrm{ClO}_{2}^{-}$(Figures 3A,B). A minor amount of $\mathrm{CO}_{2}(<1 \mu$ mole) was produced (Figure $3 \mathrm{C})$. Nearly half ( $40 \mu$ moles) of the added $\mathrm{ClO}_{2}^{-}$remained unreacted at the end of the experiment.

\section{MIXED CULTURES OXIDIZED $\mathrm{CH}_{\mathbf{4}}$}

Methane was oxidized by methanotrophic bacteria M. capsulatus Bath (Figure 4A) and M. album BG8 (Figure 4B) during the reaction of D. agitata $\mathrm{CKB}$ with $\mathrm{ClO}_{2}^{-}$. No removal of $\mathrm{CH}_{4}$ was observed in mixed cell suspensions amended with $\mathrm{ClO}_{4}^{-}$or $\mathrm{ClO}_{3}^{-}$ (i.e., no added $\mathrm{ClO}_{2}^{-}$). Methane consumption occurred while the methanotrophs were in direct contact with up to $10 \mathrm{mM} \mathrm{ClO}_{2}^{-}$. Methane removal during incubations of co-cultures of $D$. agitata $\mathrm{CKB}$ with $M$. capsulatus Bath at $37^{\circ} \mathrm{C}$ occurred within 1 day while removal of $\mathrm{CH}_{4}$ by $M$. album BG8 at $28^{\circ} \mathrm{C}$ occurred over 4 days. Similar rates of $\mathrm{CH}_{4}$ consumption were observed for these mixed cultures whether they were segregated or co-mingled 


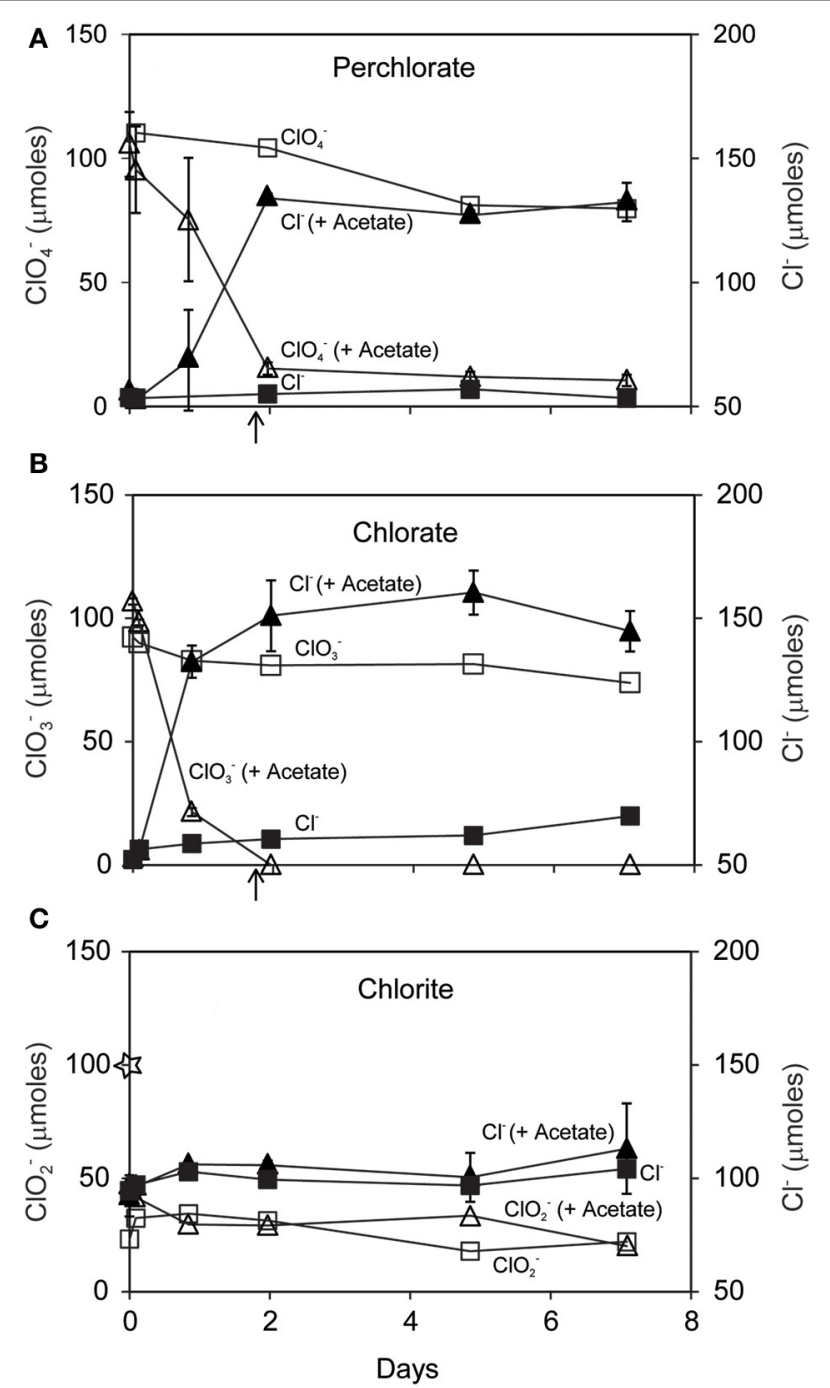

FIGURE 1 | Time course of reaction of $D$. agitata CKB following addition of $10 \mathrm{mM} \mathrm{ClO}-(A), \mathrm{ClO}_{3}^{-}(\mathrm{B})$, or $\mathrm{ClO}_{2}^{-}$(C) showing consumption of added substrate (open symbols) and production of $\mathbf{~ C l}^{-}$(closed symbols). Triangles symbolize incubations with added acetate (5 $\mathrm{mM})$ while squares symbolize incubations without added acetate. Triangles represent the mean and range of duplicate samples. Absence of bars indicates that the error is smaller than the symbol size. Squares represent single samples. Arrows in (A) and $(\mathbf{B})$ correspond to the time when $5 \mathrm{mM}$ added acetate was completely consumed. The star in (C) corresponds to the initial amount of $\mathrm{ClO}_{2}^{-}$added.

(Figure 4B) indicating that direct contact of cells was not required for methane consumption to occur.

\section{MIXED CULTURES OXIDIZE ${ }^{14} \mathrm{CH}_{\mathbf{4}}$ TO ${ }^{14} \mathrm{CO}_{\mathbf{2}}$}

Strain M. trichosporium OB3b co-cultured with D. agitata CKB containing $5 \mathrm{mM}$ acetate oxidized ${ }^{14} \mathrm{CH}_{4}$ directly to ${ }^{14} \mathrm{CO}_{2}$ (Figure 5). The rate of ${ }^{14} \mathrm{CH}_{4}$ loss under anaerobic conditions with $5 \mathrm{mM}$ added $\mathrm{ClO}_{2}^{-}$was similar to that under aerobic conditions. No loss of ${ }^{14} \mathrm{CH}_{4}$ occurred in mixed cell suspensions amended with $5 \mathrm{mM} \mathrm{ClO}_{4}^{-}$in lieu of $\mathrm{ClO}_{2}^{-}$or in controls without methanotrophs. During the incubation, the product of
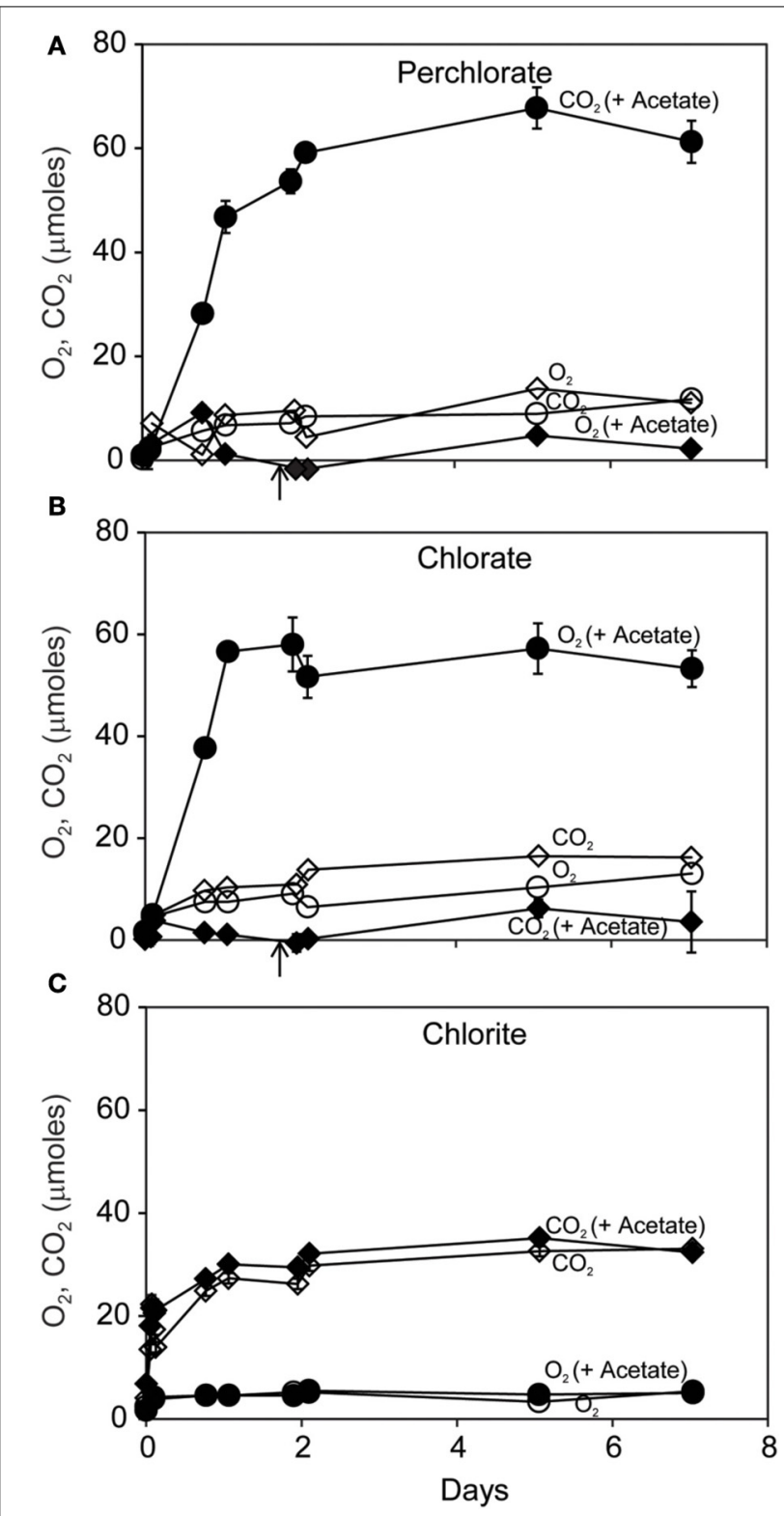

FIGURE 2 | Time course of reaction of $D$. agitata CKB following addition of $10 \mathrm{mM} \mathrm{ClO}_{4}^{-}(\mathrm{A}), \mathrm{ClO}_{3}^{-}(\mathrm{B})$, or $\mathrm{ClO}_{2}^{-}$(C) showing production of gaseous products $\mathrm{O}_{2}$ (diamonds) and $\mathrm{CO}_{2}$ (circles), with (solid symbols), and without (open symbols) $\mathbf{5} \mathbf{~ m M}$ acetate. Solid symbols represent the mean and range of duplicate samples. Absence of bars indicates that the error is smaller than the symbol size. Open symbols represent single samples. Arrows in (A) and (B) correspond to the time when $5 \mathrm{mM}$ added acetate was completely consumed.

methanotrophy $\left({ }^{14} \mathrm{CO}_{2}\right)$ was distributed about equally between liquid and gas phases. Roughly $20 \%$ of the added ${ }^{14} \mathrm{CH}_{4}$ appeared as ${ }^{14} \mathrm{CO}_{2}$ in the headspace after $20 \mathrm{~h}$ (0.8 days). Most of the ${ }^{14} \mathrm{CH}_{4}$ added was recovered as ${ }^{14} \mathrm{CO}_{2}(60-90 \%$ recovery after acidification).

\section{OXIDATION OF $\mathrm{CH}_{4}$ BY SOILS}

Searsville Lake sediment slurries removed repeated pulses of added $\mathrm{ClO}_{4}^{-}$during anaerobic incubations using freshwater 


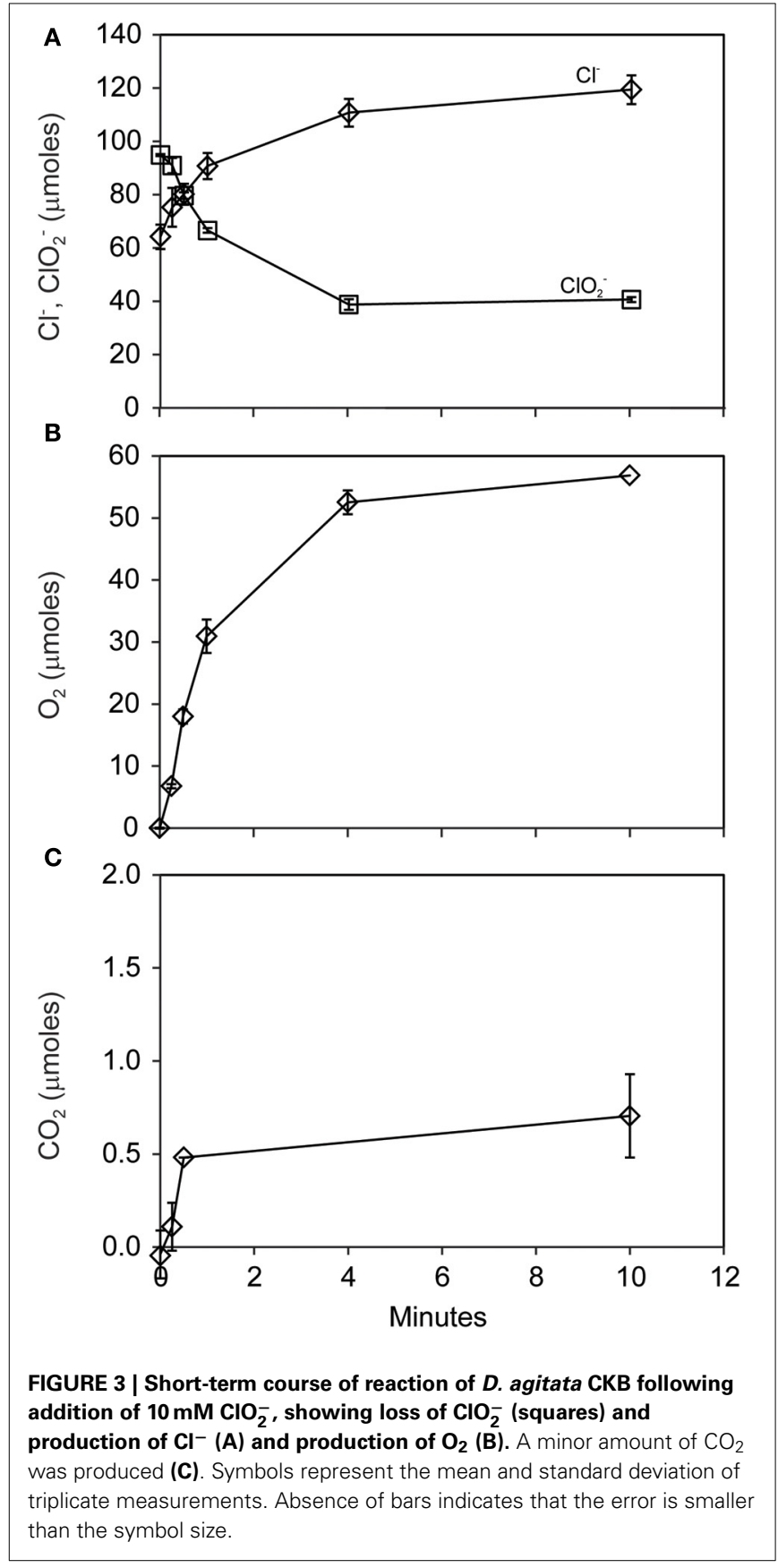

media with added acetate. Over a period of 1 month, 4 additions of $10 \mathrm{mM} \mathrm{ClO}-$ were removed in bottles with commensurate consumption of 4 additions of $5 \mathrm{mM}$ added acetate (data not shown). These slurries, thus enhanced in $\mathrm{ClO}_{4}^{-}$reducing capacity, were used in separate incubations with added $\mathrm{CH}_{4}$ (Figure 6). Under aerobic conditions, incubations with or without additions of $\mathrm{ClO}_{4}^{-}$or $\mathrm{ClO}_{2}^{-}(5 \mathrm{mM})$ completely consumed $30 \mu$ moles $\mathrm{CH}_{4}$ within 5 days. However, no oxidation of $\mathrm{CH}_{4}$ occurred during anaerobic incubations of Searsville Lake sediment slurries either with or without additions of $\mathrm{ClO}_{4}^{-}$or $\mathrm{ClO}_{2}^{-}$.

Methane oxidation was observed when Searsville Lake soil (previously enhanced in methanotrophic activity) was segregated
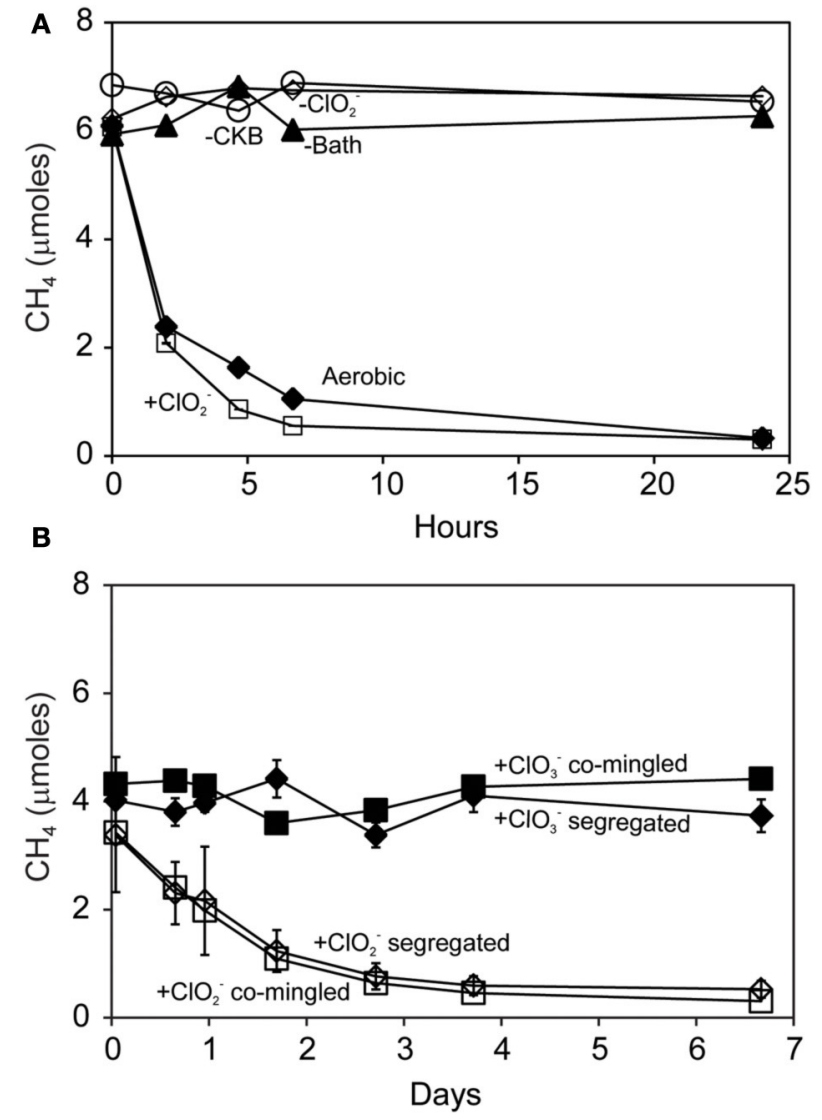

FIGURE 4 | Methane uptake by mixed cultures of $D$. agitata CKB with $M$. capsulatus Bath (A) and $M$. album BG8 (B) during anaerobic incubations. Cultures in (A) were co-mingled and provided with $5 \mathrm{mM}$ $\mathrm{ClO}_{2}^{-}$(open squares). Aerobic controls are also shown (solid diamonds). Negative controls were prepared by withholding M. capsulatus Bath (solid triangles), D. agitata $\mathrm{CKB}$ (open circles), or $\mathrm{ClO}_{2-}$ (open diamonds). Cultures in (B) were either co-mingled (squares) or segregated under a common headspace (diamonds) and provided with either $\mathrm{ClO}_{2}^{-}$(open symbols) or $\mathrm{ClO}_{3}^{-}$(solid symbols). Symbols represent the mean and standard deviation of triplicate measurements. Absence of bars indicates that the error is smaller than the symbol size.

from liquid cultures of $D$. agitata CKB. Methane was completely consumed over the next 5 days by soil methanotrophs during the

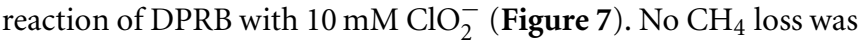
observed when DPRB were provided with either $10 \mathrm{mM} \mathrm{ClO}_{4}^{-}$or $\mathrm{ClO}_{3}^{-}$.

\section{DISCUSSION}

Few enzymes outside of photosystem II are capable of generating dioxygen in anoxic settings. In addition to chlorite dismutase (Cld), these include superoxide dismutase and catalase (McCord et al., 1971), and a putative nitric oxide dismutase (Ettwig et al., 2012). Chlorite dismutase has been purified from at least four DPRB (Mehboob et al., 2009) and is well studied (Coates et al., 1999b; Lee et al., 2008; Goblirsch et al., 2010, 2011). It is a heme enzyme which operates hyperselectively; its assumed sole function is to detoxify $\mathrm{ClO}_{2}^{-}$. The present study is the first report of anaerobic methane oxidation linked to the combined presence of DPRB and $\mathrm{ClO}_{2}^{-}$. We emphasize that this is a "cryptic" aerobic methane oxidation in that the organisms oxidizing 


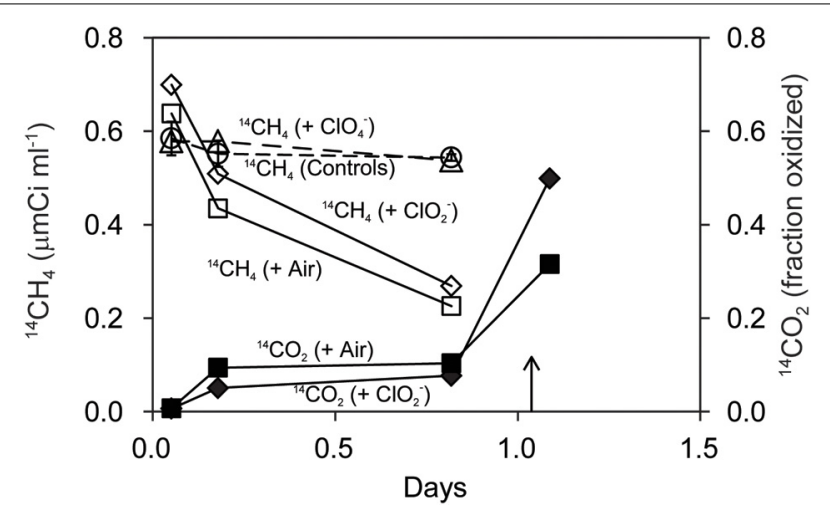

FIGURE 5 | Oxidation of ${ }^{14} \mathrm{CH}_{4}$ (open symbols) to ${ }^{14} \mathrm{CO}_{2}$ (closed symbols) by $M$. trichosporium $\mathrm{OB} 3 \mathrm{~b}$ during anaerobic incubations with $D$. agitata CKB following addition of $\mathrm{ClO}_{4}^{-}$(triangles) and $\mathrm{ClO}_{2}^{-}$ (diamonds). Triangles represent the mean and standard deviation of triplicate measurements of samples with $\mathrm{ClO}_{4}^{-}$added. All others were single bottles. Controls (no bacteria or no chloroxyanion added) were pooled and are shown as circles with error bars. Aerobic incubations with $M$. trichosporium OB3b alone are also shown (squares). Samples were acidified at the time indicated by the arrow.

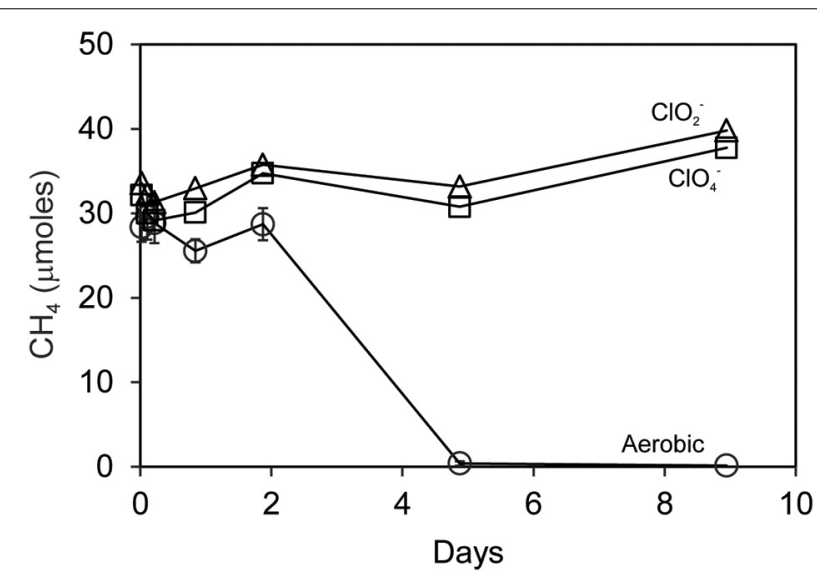

FIGURE 6 | Methane uptake by Searsville Lake sediment slurries pre-adapted to reduce perchlorate using acetate as electron donor. Anaerobic incubations with $5 \mathrm{mM}$ added $\mathrm{ClO}_{4}^{-}$(squares) or $\mathrm{ClO}_{2}^{-}$(triangles) showed no uptake. Aerobic incubations (circles) represent the mean and standard deviation of $\mathrm{CH}_{4}$ measurements in all bottles aerobic.

methane are aerobic methanotrophs as opposed to anaerobic methanogenic archaea utilizing reverse methanogenesis to consume methane (Hinrichs et al., 1999). As such, this process is somewhat analogous to nitrite-dependent anaerobic methane oxidation as purportedly carried out by the mixed culture containing Methylomirabalis oxyfera (Ettwig et al., 2010). In our study, methanotrophs use $\mathrm{O}_{2}$ derived from disproportionation of $\mathrm{ClO}_{2}^{-}$by DPRB (reaction 1) to oxidize $\mathrm{CH}_{4}$ (reaction 3 ). This is in contrast to the mechanism proposed for M. oxyfera in which a single organism may use $\mathrm{O}_{2}$ from disproportionation of $\mathrm{NO}$ derived from $\mathrm{NO}_{2}-$ (reaction 4) to oxidize $\mathrm{CH}_{4}$ (reaction 5):

$$
\begin{aligned}
2 \mathrm{NO} \rightarrow & \mathrm{N}_{2}+\mathrm{O}_{2} \quad \Delta \mathrm{G}^{\mathrm{o}^{\prime}}=-173 \mathrm{~kJ} / \mathrm{mol} \mathrm{O}_{2}(4) \\
3 \mathrm{CH}_{4}+8 \mathrm{NO}_{2}^{-}+8 \mathrm{H}^{+} \rightarrow \quad & 3 \mathrm{CO}_{2}+4 \mathrm{~N}_{2}+10 \mathrm{H}_{2} \mathrm{O} \\
& \Delta \mathrm{G}^{\mathrm{o}^{\prime}}=-928 \mathrm{~kJ} / \mathrm{mol} \mathrm{CH}_{4}
\end{aligned}
$$

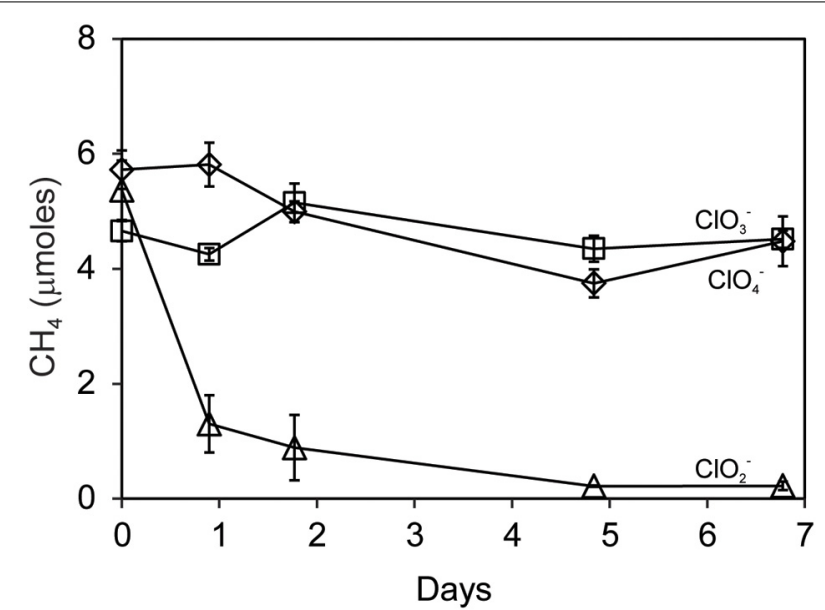

FIGURE 7 | Methane uptake by Searsville Lake soils during anaerobic incubations with $D$. agitata CKB following addition of $\mathrm{ClO}_{2}^{-}$(triangles), $\mathrm{ClO}_{4}^{-}$(diamonds), or $\mathrm{ClO}_{3}^{-}$(squares). Symbols represent the mean and standard deviation of triplicate measurements. Absence of bars indicates that the error is smaller than the symbol size.

Previous work by Coates et al. (1998, 1999a); Coates and Achenbach (2006) demonstrated a link between Cld activity and other aerobic hydrocarbon oxidizing bacteria during the degradation of benzene and naphthalene. In their experiments with pristine soil and hydrocarbon contaminated sediment, ${ }^{14} \mathrm{C}$-benzene was oxidized to ${ }^{14} \mathrm{CO}_{2}$ over several days when provided with $\mathrm{ClO}_{2}^{-}$in the presence of washed cells of D. agitata $\mathrm{CKB}$ under anoxic conditions. Similarly, ${ }^{14} \mathrm{C}$-napthalene was rapidly oxidized to ${ }^{14} \mathrm{CO}_{2}$ in the presence of washed cells of D. agitata $\mathrm{CKB}$ and Pseudomonas sp. strain JS150 (an aerobic hydrocarbon oxidizer) when provided with $\mathrm{ClO}_{2}^{-}$.

Here we demonstrated that $\mathrm{O}_{2}$ released by the reaction of $\mathrm{ClO}_{2}^{-}$with pure cultures of DPRB could be utilized by a variety of methane oxidizing bacteria, including $\gamma$-Proteobacteria (M. capsulatus Bath and M. album BG8) and $\alpha$-Proteobacteria (M. trichosporium OB3b) methanotrophs. Addition of $10 \mathrm{mM}$ $\mathrm{ClO}_{2}^{-}$to DPRB resulted in only $40-60 \%$ recovery as $\mathrm{O}_{2}$ and $\mathrm{Cl}^{-}$ (Figure 3). This may be attributed to a toxic effect of elevated $\mathrm{ClO}_{2}^{-}$or bleaching of the Cld enzyme (Streit and DuBois, 2008). Nonetheless, much of the available $\mathrm{O}_{2}$ was freely released during the reaction of $\mathrm{ClO}_{2}^{-}$with $D$. agitata $\mathrm{CKB}$, consistent with localization of Cld in the periplasm of DPRB (O'Connor and Coates, 2002). We demonstrated that direct addition of 5 or $10 \mathrm{mM} \mathrm{ClO}_{2}^{-}$ to mixed cultures of DPRB and methanotrophs did not inhibit the methanotrophs. We also showed that direct contact between the cells was not required as $\mathrm{CH}_{4}$ oxidation also occurred when the cells were contained in separate compartments under a common headspace. We further showed that ${ }^{14} \mathrm{CH}_{4}$ was quantitatively oxidized to ${ }^{14} \mathrm{CO}_{2}$ by the methanotrophs in culture. Our conclusion is that methane oxidizers utilized $\mathrm{O}_{2}$ provided by the dismutation of $\mathrm{ClO}_{2}^{-}$by DPRB.

We were unable to link methane oxidation to perchlorate or chlorate reduction. Small amounts of oxygen were produced when cultures of $D$. agitata $\mathrm{CKB}$ were amended with $\mathrm{ClO}_{4}^{-}$or 
$\mathrm{ClO}_{3}^{-}$(Figure 2), however methane was not consumed during co-culturing with methanotrophs (Figures 4, 6). This was previously observed for benzene and naphthalene (Coates et al., 1999b; Coates and Achenbach, 2006) and may be explained by $\mathrm{O}_{2}$ scavenging attributable to other processes, including activation of a terminal oxidase during (per)chlorate reduction (Rikken et al., 1996). It is also possible that slower kinetics of $\mathrm{ClO}_{4}^{-}$and $\mathrm{ClO}_{3}^{-}$ reduction limits the production and subsequent dismutation of $\mathrm{ClO}_{2}^{-}$and therefore release of $\mathrm{O}_{2}$. Relief of this bottleneck could lead to more $\mathrm{O}_{2}$ being available to aerobic methanotrophs and stimulation of the unique process described herein.

In-situ oxidation of $\mathrm{CH}_{4}$ using $\mathrm{O}_{2}$ derived from chlorite dismutation may be useful in removing elevated levels of $\mathrm{CH}_{4}$ in subsurface environments. Chlorite is $10^{4}$ times more soluble in water than $\mathrm{O}_{2}$ and could be easily and safely directed to the anaerobic zone (where methane may be present) during bioremediation. One example is enhanced oxidation of landfill methane without the use of forced air, reducing the risk of fire and explosion. The ability of methanotrophs and DPRB to function in separate compartments under a common headspace could be exploited at distal stages of oil development, for instance at well heads where unusable $\mathrm{CH}_{4}$ is typically flared off to reduce transportation costs or risk. In addition, production of $\mathrm{CO}_{2}$ formed during oxidation of $\mathrm{CH}_{4}$ may be viewed similarly to injected $\mathrm{CO}_{2}$ in efforts to dissolve and flush oil from developed petroleum reservoirs (Blunt et al., 1993). Further, bioclogging by cells and biocementation resulting from carbonate precipitation may be enhanced by the growth and activity of microbes capable of linking methane oxidation with (per)chlorate reduction. Bioclogging and biocementation are features of microbial enhanced hydrocarbon recovery most likely to be exploited by geotechnologists to direct hydrocarbon flow into more permeable substrates in order to enhance recovery. However, it must be noted that we observed no methane oxidation in water saturated soils exposed to both $\mathrm{CH}_{4}$ and $\mathrm{ClO}_{2}^{-}$(Figure 6) indicating that $\mathrm{O}_{2}$ derived from chlorite dismutation may face transport limitations in saturated anaerobic environments and may be consumed before reaching nearby $\mathrm{CH}_{4}$. Even under our unsaturated experimental conditions where liquid cultures and soil were segregated under a common headspace (Figure 7) the amount of soil present in each microcosm had to be optimized in order to balance methanotrophy with other soil $\mathrm{O}_{2}$ utilizing processes.

Oxidation of $\mathrm{CH}_{4}$ by the mechanism identified here may reduce the greenhouse impact of fugitive gases during hydrocarbon reservoir development and recovery because the global warming potential of $\mathrm{CO}_{2}$ is 25 times lower than $\mathrm{CH}_{4}$ on a 100 year time scale (IPCC 5th assessment, 2013). In addition, intermediates along the pathway of aerobic methane oxidation (e.g., methanol, formaldehyde, and formate) are themselves quite useful as chemical feedstocks for a myriad of industrial applications including biofuel production.

\section{ACKNOWLEDGMENTS}

We thank Jeremy Semrau and Jeongdai Im for supplying methanotrophic cultures. Nona Chiariello and Philippe Cohen provide access to Jasper Ridge Biological Preserve and Searsville Lake. Stacy Bennett assisted in the lab. Financial support was provided by USGS National Research Program and NASA Exobiology and Evolutionary Biology Program.

\section{REFERENCES}

Blunt, M., Fayers, J. F., and Orr, F. M. Jr. (1993). Carbon dioxide in enhanced oil recovery. Energy Convers. Manag. 34, 1197-1204. doi: 10.1016/01968904(93)90069-M

Boetius, A., Ravenschlag, K., Schubert, C. J., Rickert, D., Widdel, F., Gieseke, A., et al. (2000). A marine microbial consortium apparently mediating anaerobic oxidation of methane. Nature 407, 623-626. doi: 10.1038/35036572

Carlström, C. I., Wang, O., Melnyk, R. A., Bauer, S., Lee, J., Engelbrekston, A., et al. (2013). Physiology and genomic description of the novel marine dissimilatory perchlorate reducing bacterium Arcobacter sp. strain CAB. MBio 4:e00217-e00213. doi: 10.1128/mBio.00217-13

Cicerone, R. J., and Oremland, R. S. (1988). Biogeochemical aspects of atmospheric methane. Global Biogeochem. Cycles 4, 299-327. doi: 10.1029/GB002i004 p00299

Coates, J. D., and Achenbach, L. A. (2004). Microbial perchlorate reduction: rocket fueled metabolism. Nat. Rev. Microbiol. 2, 569-580. doi: 10.1038/nrmicro926

Coates, J. D., and Achenbach, L. A. (2006). "The microbiology of perchlorate reduction and its bioremediative application," in Perchlorate: Environmental Occurrence, Interactions and Treatment, eds B. Gu and J. D. Coates (New York, NY: Springer), 279-295. doi: 10.1007/0-387-31113-0_12

Coates, J. D., Bruce, R. A., and Haddock, J. D. (1998). Anoxic bioremediation of hydrocarbons. Nature 396:730. doi: 10.1038/25470

Coates, J. D., Bruce, R. A., Patrick, J. A., and Achenbach, L. A. (1999a). Hydrocarbon bioremediative potential of (per)chlorate-reducing bacteria. Bioremed. J. 3, 323-334. doi: 10.1080/10889869991219415

Coates, J. D., Michaelidou, U., Bruce, R. A., O’Connor, S. M., Crespi, J. N., and Achenbach, L. A. (1999b). The ubiquity and diversity of dissimilatory (per)chlorate-reducing bacteria. Appl. Environ. Microbiol. 65, 5234-5241.

Culbertson, C. W., Zehnder, A. J. B., and Oremland, R. S. (1981). Anaerobic oxidation of acetylene by estuarine sediments and enrichment cultures. Appl. Environ. Microbiol. 41, 396-407.

Ettwig, K. F., Butler, M. K., Le Paslier, D., Pelletier, E., Mangenot, S., Kuypers, M. M., et al. (2010). Nitrite-driven anaerobic oxidation of methane by oxygenic bacteria. Nature 464, 543-548. doi: 10.1038/nature08883

Ettwig, K. F., Speth, D. R., Reimann, J., Wu, M. L., Jetten, M. S. M., and Keltjens, J. T. (2012). Bacterial oxygen production in the dark. Front. Microbiol. 3:273. doi: $10.3389 /$ fmicb. 2012.00273

Gieg, L. M., Duncan, K. E., and Suflita, J. M. (2008). Bioenergy production via microbial conversion of residual oil to natural gas. Appl. Environ. Microbiol. 74, 3022-3029. doi: 10.1128/AEM.00119-08

Gieg, L. M., Jack, T. R., and Foight, J. M. (2011). Biological souring and mitigation in oil reservoirs. Appl. Microbiol. Biotechnol. 92, 263-282. doi: 10.1007/s00253011-3542-6

Goblirsch, B. R., Kurker, R. C., Streit, B. R., Wilmot, C. M., and DuBois, J. L. (2011). Chlorite dimutases, DyPs, and EfeB: 3 microbial heme enzyme families comprise the CDE structural superfamily. J. Mol. Biol. 408, 379-398. doi: 10.1016/j.jmb.2011.02.047

Goblirsch, B. R., Streit, B. R., DuBois, J. L., and Wilmot, C. M. (2010). Structural features promoting dioxygen production by Dechloromonas aromatica chlorite dismutase. J. Biol. Inorg. Chem. 15, 879-888. doi: 10.1007/s00775-0100651-0

Hinrichs, K. U., Hayes, J. M., Sylva, S. P., Brewer, P. G., and DeLong, E. F. (1999). Methane-consuming archaebacteria in marine sediments. Nature 398, 802-805. doi: 10.1038/19751

Hobbie, J. E., Daley, R. L., and Jaspar, S. (1977). Use of Nuclepore filters for counting bacteria for fluorescence microscopy. Appl. Environ. Microbiol. 33, 1225-1228.

Hoeft, S. E., Kulp, T. R., Stolz, J. F., Hollibaugh, J. T., and Oremland, R. S. (2004). Dissimilatory arsenate reduction with sulfide as electron donor: experiments with Mono Lake water and isolation of strain MLMS-1, a chemoautotrophic arsenate respirer. Appl. Environ. Microbiol. 70, 2741-2747. doi: 10.1128/AEM.70.5.2741-2747.2004

IPCC Working group 1 contribution to the 5 th assessment report. (2013). Climate Change 2013: The Physical Science Basis. Stockholm. 
Jenneman, G. E., Knapp, R. M., McInerney, M. J., Menzie, D. E., and Revus, D. E. (1984). Experimental studies of in-situ microbial enhanced oil recovery. Soc. Petrol. Eng. J. 24, 35-37. doi: 10.2118/10789-PA

Jones, D. M., Head, I. M., Gray, N. D., Adams, J. J., Rowan, A. K., Aitken, C. M., et al (2007). Crude-oil biodegradation via methanogenesis in subsurface petroleum reservoirs. Nature 451, 176-181. doi: 10.1038/nature06484

Kostan, J., Sjöblom, B., Maixner, F., Mlynek, G., Furtmüller, P. G., Obinger, C., et al. (2010). Structural and functional characterisation of the chlorite dismutase from the nitrite-oxidizing bacterium "Candidatus Nitrospira defluvii": identification of a catalytically important amino acid residue. J. Struct. Biol. 172, 331-342. doi: 10.1016/j.jsb.2010.06.014

Kounaves, S. P., Stroble, S. T., Anderson, R. M., Moore, Q., Catling, D. C., Douglas, S., et al. (2010). Discovery of natural perchlorate in the Antarctic dry valleys and its global implications. Environ. Sci. Technol. 44, 2360-2364. doi: $10.1021 /$ es 9033606

Lazar, I., Petrisor, I. G., and Yen, T. F. (2007). Microbial Enhanced Oil Recovery. Petrol. Sci. Technol. 25, 1353-1366. doi: 10.1080/109164607012 87714

Lee, A. Q., Streit, B. R., Zdilla, M. J., Abu-Omar, M. M., and DuBois, J. L. (2008). Mechanism of and exquisite selectivity for O-O bond formation by the hemedependent chlorite dismutase. Proc. Nat. Acad. Sci. U.S.A. 105, 15654-15659. doi: 10.1073/pnas.0804279105

Martini, A. M., Budai, J. M., Walter, L. M., and Schoell, M. (1996). Microbial generation of economic accumulations of methane within a shallow organic-rich shale. Nature 383, 155-158. doi: 10.1038/383155a0

McCord, J. M., Keele, B. B. Jr., and Fridovich, I. (1971). An enzyme-based theory of obligate anaerobiosis: the physiological function of superoxide dismutase. Proc. Natl. Acad. Sci. U.S.A. 68, 1024-1027. doi: 10.1073/pnas.68.5.1024

Mehboob, F., Wolterink, A. F. M., Vermeulen, A. J., Jiang, B., Hagedoorn, P.-L., Stams, A. J. M., et al. (2009). Purification and characterization of a chlorite dismutase from Pseudomonas chloritidismutans. FEMS Microbiol. Lett. 293, 115-121. doi: 10.1111/j.1574-6968.2009.01517.x

Miller, L. G., Baesman, S. M., Kirshtein, J., Voytek, M. A., and Oremland, R. S. (2013). A biogeochemical and genetic survey of acetylene fermentation by environmental samples and bacterial isolates. Geomicrobiol. J. 30, 501-516. doi: 10.1080/01490451.2012.732662

Miller, L. G., Baesman, S. M., and Oremland, R. S. (2003). Bioreactors for removing methyl bromide following contained fumigations. Environ. Sci. Technol. 37, 1698-1704. doi: 10.1021/es026155j

Milucka, J., Ferdelman, T. G., Polerecky, L., Franzke, D., Wegener, G., Schmid, M., et al. (2012). Zero-valent sulfur is a key intermediate in marine methane oxidation. Nature 491, 541-546. doi: 10.1038/nature11656

Mlynek, G., Sjöblom, B., Kostan, J., Füreder, S., Maixner, F., Gysel, K., et al. (2011). Unexpected diversity of chlorite dismutases: a catalytically efficient dimeric enzyme from Nitrobacter winogradskyi. J. Bacteriol. 193, 2408-2417. doi: 10.1128/JB.01262-10

O'Connor, S. M., and Coates, J. D. (2002). Universal immunoprobe for (per)chlorate-reducing bacteria. Appl. Environ. Microbiol. 68, 3108-3113. doi: 10.1128/AEM.68.6.3108-3113.2002

Oremland, R. S., and Culbertson, C. W. (1992). Importance of methane oxidizing bacteria in the methane budget as revealed by the use of a specific inhibitor Nature 356, 421-423. doi: 10.1038/356421a0
Rao, B., Anderson, T. A., Orris, G. J., Rainwater, K. A., Rajagopalan, S., Sandvig, R. M., et al. (2007). Widespread natural perchlorate in unsaturated zones of the southwest United States. Environ. Sci. Techol. 441, 4522-4528. doi: $10.1021 /$ es062853i

Rikken, G. B., Kroon, A. G. M., and van Ginkel, C. G. (1996). Transformation of (per)chlorate into chloride by a newly isolated bacterium: reduction and dismutation. Appl. Microbiol. Biotechnol. 45, 420-426. doi: 10.1007/s002530050707

Streit, B. R., and DuBois, J. L. (2008). Chemical and steady-state kinetic analysis of a heterologously expressed heme enzyme dependent chlorite dismutase. Biochemistry 47, 5271-5280. doi: 10.1021/bi800163x

Sun, W., Sierra-Alvarez, R., Milner, L., and Field, J. A. (2010). Anaerobic oxidation of arsenite linked to chlorate reduction. Appl. Environ. Microbiol. 76, 6804-6811. doi: 10.1128/AEM.00734-10

Sun, Y., Gustavson, R. L., Ali, N., Weber, K. A., Westphal, L. L., and Coates, J. D. (2009). Behavioral response of dissimilatory perchlorate-reducing bacteria to different electron acceptors. Appl. Microbiol. Biotehnol. 84, 955-963. doi: 10.1007/s00253-009-2051-3

Urbansky, E. T. (2002). Perchlorate as an environmental contaminant. Environ. Sci. Poll. Res. 9, 187-192. doi: 10.1007/BF02987487

Weelink, S. A. B., Tan, N. C. G., ten Boreke, H., van Doesburg, W., Langenhoff, A. A. M., Gerritse, J., et al. (2007). Physiological and phylogenetic characterization of a stable benzene-degrading, chlorate-reducing microbial community. FEMS Microbiol. Ecol. 60, 312-321. doi: 10.1111/j.1574-6941.2007.00289.x

Whittenbury, R., Phillips, K. C., and Wilkinson, J. F. (1970). Enrichment, isolation and some properties of methane-utilizing bacteria. J. Gen. Microbiol. 61, 205-218. doi: 10.1099/00221287-61-2-205

Youseff, N., Elshahed, M. S., and McInerney, M. J. (2009). "Microbial processes in oil fields: culprits, problems, and opportunities," in Advances in Applied Microbiology, ed A. I. Laskin, S. Sariaslani, and G. M. Gadd (Burlington: Academic Press, Elsevier Inc.) 141-251.

Zhu, H., Carlson, H. K., and Coates, J. D. (2013). Applicability of anaerobic nitrate-dependent $\mathrm{Fe}(\mathrm{II})$ oxidation to microbial enhanced oil recovery (MEOR). Environ. Sci. Technol. 47, 8970-8977. doi: 10.1021/es401838b

Conflict of Interest Statement: The Guest Associate Editor Hans Carlson declares that, despite having collaborated with author John Coates, the review process was handled objectively. The authors declare that the research was conducted in the absence of any commercial or financial relationships that could be construed as a potential conflict of interest.

Received: 31 January 2014; accepted: 19 May 2014; published online: 17 June 2014 Citation: Miller LG, Baesman SM, Carlström CI, Coates JD and Oremland RS (2014) Methane oxidation linked to chlorite dismutation. Front. Microbiol. 5:275. doi: $10.3389 /$ fmicb.2014.00275

This article was submitted to Microbial Physiology and Metabolism, a section of the journal Frontiers in Microbiology.

Copyright (c) 2014 Miller, Baesman, Carlström, Coates and Oremland. This is an open-access article distributed under the terms of the Creative Commons Attribution License (CC BY). The use, distribution or reproduction in other forums is permitted, provided the original author(s) or licensor are credited and that the original publica tion in this journal is cited, in accordance with accepted academic practice. No use, distribution or reproduction is permitted which does not comply with these terms. 